\title{
Kingship and 'State' in Torah, History, and Poetry: Exploring the risk of terminological anachronism in Old Testament scholarship
}

\author{
Johanna Friedl (University of Pretoria, South Africa / \\ AUSTRIAN ACADEMY OF SCIENCES)
}

\begin{abstract}
In exploring the constituent elements of our modern-day nation state, this contribution wishes to highlight those areas in which anachronism might arise in Old Testament interpretations of 'state'. This might happen due to the influence of deeply-rooted modern-day conceptions, according to which a state consists of a people group living within a distinct territory, governed by a body holding jurisdiction over both people and territory. This contribution explores pre-exilic, exilic, and post-exilic biblical texts containing the elements of people, land, and king, asking whether these texts wish to convey a political or rather a theological message.
\end{abstract}

KEYWORDS: State theory; people (עם); land; kingship; Deuteronomic Law of the King

\section{A INTRODUCTION: MODERN-DAY CONCEPTS OF 'STATE' AND ITS CONSTITUENT ELEMENTS}

Great early political or state theorists include, in antiquity, Plato and Aristotle, in the early Christian tradition Augustine and Thomas Aquinas, and then, in radical discontinuity with the Christian tradition, Niccolò Machiavelli, who represents a hinge between Renaissance and modern thought. Whereas Antiquity and Scholasticism principally had the ideal of eudaimonia in mind when conceptualising human coexistence, Modernity had to grapple with the problem of numerous wars and conflicts, both of a civil and inter-national nature. Now, mere survival was at stake. ${ }^{1}$ Internal upheaval especially within France and the British kingdom gave impetus to the considerations of absolutists such as Jean Bodin, Sir Robert Filmer, and Thomas Hobbes, all of whom wished for a powerful state, which could ward off the danger of war and conflict. Their contemporary John Locke is often called their counterpart and the father of liberalism, but although he rejected absolutism and made great progress

* Submitted: 10/09/2019; peer-reviewed: 08/04/2020; accepted: 08/05/2020. Johanna Friedl "Kingship and 'State' in Torah, History, and Poetry: Exploring the risk of terminological anachronism in Old Testament scholarship," Old Testament Essays 33 no. 2 (2020): 232 - 249. DOI: https://doi.org/10.17159/2312-3621/2020/v33n2a5. 1 Cf. Katharina von Schlieffen \& Jenny Nolting, Rechtsphilosophie. Grundlagen für das Jurastudium (Paderborn: Verlag Ferdinand Schöningh, 2018), 176. 
formulating the concepts later developing into liberalism, he also thought about private property, trust and social contract, democratic sovereignty, and the separation of powers. Order and structure of course were still important to him, too. He directly influenced the formation of the ideas of the constitution of the United States of America on the one hand, and to a lesser degree that of the French Revolution, especially in his influence on the thought of Jean-Jacques Rousseau. $^{2}$

A state-like construct would contain the elements of an established solidarity between a group of people and a hierarchy of power regulating certain social functions of the group. Modern European conceptions of statehood add to the basic idea of the people-hierarchy-interaction the notion of a geographically delimited sovereign territory within which this interaction is to be lived. A short formula for the three constituting elements of statehood would be people, territory, and jurisdiction (monopoly of power). ${ }^{3}$ We may now consider these three constituent elements of state within their temporal context.

\section{B 'PEOPLE' IN MEDIEVAL, MODERN, AND BIBLICAL THOUGHT}

Excluding the implications that a mammoth construct such as the European Union might have for the understanding of the human element of a state and focusing on the nation-state, its 'people' are today considered to be those living within the boundaries of the state (within state territory). The 'people' of a nation-state are understood especially to be those enjoying the privileges of citizenship, such as carrying a national passport and having the right to vote in elections. They typically, however not necessarily, share a common language an aspect that becomes less important in situations where global migration escalates. Currently, it is migration that causes society to re-think the classic conception of a national people, and we shall see that the Bible presents a yet different conception of that which it designates as a 'people'.

In late antique and medieval texts, a number of related terms served to express the identity of a somehow related group of people in relation to the

2 Cf. the concise summary of historical developments of political thought offered in Von Schlieffen and Nolting, Rechtsphilosophie. The editions of Sir Robert Filmer, Patriarcha and other Writings. Edited by Johann P. Sommerville (Cambridge: Cambridge University Press, 1991); Thomas Hobbes, Leviathan. Edited with an Introduction and Notes by J.C.A. Gaskin (Oxford: Oxford University Press, 1996), and John Locke, Two Treatises of Government. Edited with an Introduction and Notes by Peter Laslett (Cambridge: Cambridge University Press, 1988) contain excellent, detailed introductions to these historically important works and their temporal and situational backgrounds.

3 Cf. Josef Isensee, "Staat," in Handbuch der Katholischen Soziallehre (ed. Anton Rauscher; Berlin: Duncker \& Humblot, 2008), 743. 
geographical area in which they are settled and in which they live in a socially coherent context. These texts use Latin terms such as populus, people (referring to the politically entitled inhabitants of an area, later however increasingly carrying a derogatory connotation); gens (denoting people sharing a common descent), and natio (used in a sense similar to the present-day notion of a tribe). These distinctions, however, were not always maintained clearly and, as is the case in our day too, usage of these terms often was vague and imprecise. ${ }^{4}$

The Hebrew word עם, commonly translated as 'people', originally was a term denoting kinship, more specifically meaning 'family', 'clan', or 'relation' .5 In Israel, families were organised agnatically or patrilineally, meaning that the bloodline was perpetuated along the male line of father, sons, and grandsons, including also the uncles, male cousins, and their sons. A typical Old Testament designation for the 'family' therefore is 'house of the father', בת אב.

In the end text of the Hebrew Bible, the word עם, however, represents a more nuanced spectrum of meaning, certainly going beyond the familial semantic field. It may refer to a military body (cf. Judg 5:2,13). The word may further refer to the assembly of the people for the purpose of covenanting with YHWH (cf. Ex 19:8). In some form of association with God, be it through the word אלהים, or in conjunction with a pronominal suffix denoting YHWH, it occurs all of 362 times, especially frequently in the prophets. ${ }^{6}$ Norbert Lohfink had proved that עם יהוה occurs substantially more frequently, namely in two-thirds of all cases, in speeches of YHWH, speeches on behalf of him or in addresses to him, than in objective, third-person accounts concerning Israel, which accounts for the other third of references. It is a term of endearment, used in situations of dialogue between YHWH and Israel. ${ }^{7}$ This clearly contradicts the opinion of Wolfgang Oswald that Israel never had thought of itself as a religious community, ${ }^{8}$ but merely as a political entity.

4 Peter H. Wilson, The Holy Roman Empire. A Thousand Years of Europe's History (London: Penguin Random House, 2017), 236f.

5 Cf. Norbert Lohfink, "Beobachtungen zur Geschichte des Ausdrucks עם יהוה" in Probleme biblischer Theologie. Gerhard von Rad zum 70. Geburtstag (ed. H.W. Wolff; München: Kaiser, 1971), 277.

6 Cf. Lohfink, "עם יהוה", 275f, 278.

7 Cf. Lohfink, "עם יהוה", $280 f$.

8 Wolfgang Oswald, "Königtum und Staat" in Die Welt der Hebräischen Bibel. Umfeld-Inhalte - Grundthemen (ed. W. Dietrich; Stuttgart: Kohlhammer, 2017), 199: "Als religiöse Gemeinschaft hat sich Israel zu keinem Zeitpunkt der alttestamentlichen Zeitgeschichte verstanden" and furthermore, ibid., 208: “...wenn man unter »Gemeinde« nicht eine religiöse Gruppe versteht". In contrast, Lothar Perlitt, "Der Staatsgedanke im Deuteronomium" in Language, Theology and the Bible: Essays in Honour of James Barr (ed. S. Balentine and J. Barton; Oxford: Clarendon Press, 1994) 
To which degree should we distinguish between the 'religious' community and the 'political' community when thinking about Israel - and does the degree of distinction vary in the pre-exilic, exilic, and post-exilic periods?

An important pre-exilic source ${ }^{9}$ of information would be the Song of Deborah (Judg 5) which mentions Israel nine times ${ }^{10}$, in V. 2 directly associating עם with עם יהוה In the second section of the Song of Deborah, Judg 5:14-23, the focus is not on the people as a whole, but the poem describes the actions of nine tribes of Israel individually. Five of them, Benjamin, Ephraim/Machir, Zebulon, Naphtali, and Issachar, are praised for their active and heroic participation in the battle. Four, namely Dan, Gilead $^{12}$, Reuben, and Asher are rebuked for not having taken part in the conflict. Simeon and Judah receive no mention at all, and Levi, having been the priestly tribe without territory ${ }^{13}$, could not participate in battle and thus does not feature

presents an alternative approach to the question of state in Deuteronomy, which will be introduced in section D of this contribution.

9 Cf. Walter Groß, Richter (Freiburg/Breisgau: Herder, 2009), 295-297, for arguments about the dating of the song, which he sets in the $10^{\text {th }}$ to $9^{\text {th }}$ century BC (cf. ibid., 82f). The opinion held in this contribution widely correlates with Groß's view, namely that, although no absolute arguments can be brought to bear on linguistic evidence only, it is hardly plausible that the poem, at least in its core, could be a late or very late composition (i.e., from the monarchy onwards). Groß's $10^{\text {th }} / 9^{\text {th }}$ century dating may be accepted with no great difficulty on account not only of inferences drawn from language, but also of the thematic and contextual setting of the poem.

10 Judg 5:2, 3, 5, $7^{\text {bis }}, 8,9,11,13$ - the latter reference to Israel can be counted only if the text-critical suggestion in $\mathrm{BHS}^{4}$ of reading V. 13 as such is accepted.

11 Lohfink, "עם יהוה", 281f, however argues against a complete identification with Israel on account of the military context of the text (the term thus indicates men only, excluding women and children) and of the fact that not all tribes were involved in the battle. He however soon solves this problem when he describes the development undergone by the designation 'Israel': "Zu einem bestimmten Zeitpunkt war die bezeichnete Sache normalerweise nicht mehr eine kleinere oder größere Gruppe innerhalb Israels, sondern einfach ,Israel', und Israel war ein Volk" (ibid., 286).

12 The listing of Machir in Judg 5:14b and of Gilead in Judg 5:17 should be explained, in order to verify the completeness of the tribal list. Reuben, Manasseh, and Gad were the three tribes that settled the territory of Gilead (Num 32:40; Dtn 3:12-17). Reuben is mentioned separately in Judg 5:15f, which leaves Manasseh and Gad as possible references for Gilead in Judg 5:17. Num 26:29 identifies Gilead as the son of Machir, who in turn was the son of Manasseh. This means that the traditional pairing of Manasseh and Ephraim (cf. Num 26:28) is maintained in Judg 5:14, leaving Gad as the only candidate for association with Gilead in Judg 5:17. The association of Gilead with Gad is further strengthened by the fact that both Reuben and Gilead/Gad are reprimanded (5:15f, 17), while both Ephraim and Manasseh/Machir are praised (5:14). For a slightly different interpretation and for more information on Machir, cf. Groß, Richter, 322.

13 Cf. Dtn 18:1f; Num 18:20, 23f; Jos 13:14, 33; 18:7. 
in the list either. ${ }^{14}$ The third and last section of the poem, V. 24-30, describes events taking place between Jael and Sisera, as well as his death and the mourning by his mother. Introductory and closing formulas in V. 1 and 31 frame the whole poem. In V. 2 and V. 13, the word עם frames the section of the poem containing references to Israel (V. 2-13), with one more occurrence of עם each in V. 9 and V. 11. In the case of V. 11, עם יהוה is most probably part of an addition and is often left untranslated, since the whole verse is rather problematic, and its Hebrew text is corrupt in certain instances. ${ }^{15}$

V. 11 contains another designation for the people, namely פרזון, denoting a people group living in a rural setting, which Walter Groß identifies with the inactive totality of Israel's people, excluding the inter-tribal group of warriors, the עם יהוה exilic 'people' terminology of Judg 5 might thus be: פרזון + עם יהוה = ישראל. For our purposes, it is relevant that עם is directly associated with Israel in V. 2, and with YHWH in V. 13. It has very definite military connotations - in fact, the New American Bible for instance translates עם יהוה in V. 13 with "the army of the LORD" - which, broadly speaking, places its usage firmly in a political realm. The association with יהוה', however, also firmly establishes a religious connotation.

Judg 20:1f contains an interesting combination of terms denoting the people of Israel. V. 1 first mentions 'all the Israelites' (כל־בני ישראל) coming out (יצא) and assembling as one man (ותקהל העדה כאיש אחד). The verb at the beginning of V. 1 places the events to be described in a military context, ${ }^{17}$ namely that of the slaughter among the Benjaminites after the atrocity of Judg 19:22-30. The ten assaulting tribes assemble in an action described in a uniquely concentrated combination of expressions denoting unity and totality. ${ }^{18}$

The accounts of the violence committed in Judg 19 and its consequences in Judg 20 belong to the post-exilic frame of the book. ${ }^{19}$ In this particular case,

14 The fact that the texts directly mentioning the exclusion of Levi from possessing territory are all to be dated later than the $10^{\text {th }}$ or $9^{\text {th }}$ centuries does of course raise questions on the possible historical backgrounds of the exclusion of Levi from the list in Judg 5. It might, however, simply be an early textual indication of an established practice of singling out the tribe in this manner.

15 Cf., however, the caveats expressed by Lohfink, "עם יהוה", 281 n. 25.

16 Cf. Groß, Richter, 320.

17 Cf. Groß, Richter, 848.

18 The phrase כל־בני ישראל ותקהל העדה כאיש אחד in Judg 20:1 contains no less than

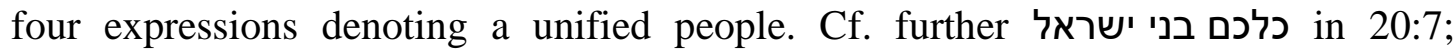

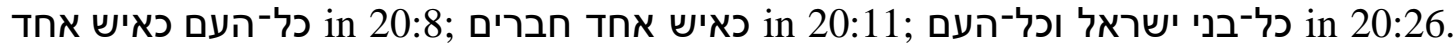
Cf. Groß, Richter, 848.

19 Cf. Groß, Richter, 92; Lohfink, עם יהוה, 282. 
the post-exilic narrative portrays the 'people' in much the same manner as did the early text of Judg 5, namely, as a military body.

Norbert Lohfink enumerates a number of early historical texts ${ }^{20}$ defining the נחיד in and with the נחלת יהוה or, for instance I Sam 9 and 10, a narrative we shall return to, recounting the installation of Saul as נגיד In Israel. The term, is analogous to but not identical ${ }^{21}$ with the king, מלך, an entity we will comprehensively deal with in the section on Jurisdiction. The term נחלה in turn is analogous to the land, which will come under our attention in the section on Territory. Exegetically it is possible, arguably, also to translate נחלת יהוה as the 'army of the LORD', which is interesting, because in this reading a 'land term' is turned into a 'people term'. ${ }^{22}$ The very association with נחלה however reminds us of the latent religious connotation of this semantic field in pre-exilic as well as post-exilic times.

\section{C 'TERRITORY' (LAND) IN MEDIEVAL, MODERN AND BIBLICAL THOUGHT}

Israel's self-conception in connection with the land, ארץ, is far removed from that of any theoretical modern people group seeing itself as entitled by state authority to live within a distinct territory. Both ארץ (land in its political sense) and נחלה (heritage) are connoted with the restriction that the piece of ground it refers to does not 'belong' to the people living on it.

Lev 25:23 is very clear about it. God speaks: 'The land shall not be sold irrevocably, for the land is mine, and you are but resident aliens and under my authority'. This verse applies the (biblically speaking, artificial) principle of Privilegrecht (the law of privileges) that Friedrich Horst had introduced for Dtn 12-18 (1930) and Jörn Halbe for Ex 34:10-26 (1975) when the two scholars associated biblical law with the medieval concept of the feudal law of privileges. Recurring to Jörn Halbe, one can define the law of privileges as the entitlement resulting when a powerful person allows (or forces) a subordinate to enter into a position of dependence. A relationship of mutual obligation determines the interaction between the two entities, and it is the mightier partner who has to provide the physical and legal framework for the exercise of these duties. ${ }^{23}$ For Lev 25:23, this would mean that it is YHWH and not the people to whom the land

20 I Sam 9:16; 13:14; 25:30 II Sam 5:2; 6:21; 7:8; I Ki 1:35; 14:7; 16:2; II Ki 20:5.

21 Cf. Gerhard Hasel, נגיד, ThWAT V: 209. The term may refer to a person designated to become king, but who is not (yet) equal to him (cf. ibid.).

22 Cf. Lohfink, עם יהוה, 284 n. 42.

23 Cf. Jörn Halbe, Das Privilegrecht Jahwes Ex 34,10-26. Gestalt und Wesen, Herkunft und Wirken in vordeuteronomischer Zeit (Göttingen: Vandenhoeck \& Ruprecht, 1975), 227. 
ultimately belongs. ${ }^{24}$ Thomas Hieke distinguishes between ownership and holding (Eigentum und Besitz), where the former would involve a legally documented right of disposal, held by God alone, and the latter would apply to God's people, enjoying the right of usage of the land without legal entitlement to it, but temporarily granted to them by God's (oral) decree. Therefore, God retains the right to order or decree that portions of land may not be sold irrevocably, but only temporarily be conveyed between usufructuaries. ${ }^{25}$

In its literal sense, נחלה, heritage or inheritance, which is often closely associated with חלק, 'portion', evokes the image of a piece of land which is allotted to an heir, which would typically be male, (cf., however, Num 27:5-10). This heir, ideally the son of the deceased land-'owner', is to continue his name and his work on earth, which provides the deceased with a future, that is, with an after-life on earth. נחלה is primarily a legal term, but it is also used figuratively for a person's lot or destiny as well as for spiritual and ethical values ${ }^{26}$, as is the case in the introduction to the Law of the Priests (Dtn 18:1f), which is thematically related to the principle of the law of privileges: 'The Levitical priests, the whole tribe of Levi, shall have no hereditary portion (חלק ונחלה) within Israel ... They shall have no heritage among their brothers; the LORD himself is their heritage, as he has told them'. Here, too, portions of land shall not be permanently conveyed into the hands of a certain people group, in this case, the Levitical priests who of course stand in direct association with YHWH himself. When He is called the נחלה of Levi, it is a case of hypallage, which is a figure of speech in which the subject and object in a sentence are changed around. In this case, it points to the fact that, in reality, it is not only God who is the (spiritual) heritage of Levi, but that Levi and the land belong to God, who holds the right of disposal for both. God's being the heritage to Levi transcends the physical realm and, as is the case in Ps $16: 5 \mathrm{f},{ }^{27}$ touches the spiritual.

Ludger Schwienhorst-Schönberger points out that Israel's conception of self, of being a people as an entity with whatever function, be it political or religious, had developed independently from its relation to the land. From its

24 John S. Bergsma, The Jubilee from Leviticus to Qumran. A History of Interpretation (Leiden: Brill, 2007), 95, refers to a "statement of principle" in the context of Lev 25,23f, which would be: "The only true owner of the land is the LORD". Christophe Nihan, From Priestly Torah to Pentateuch (Tübingen: Mohr Siebeck, 2007), 521, identifies "two essential motivations of the law" in V. 23 ("the land belongs to Yahweh exclusively") and V. 55 ("the Israelites belong to Yahweh"). Cf. similarly Thomas Hieke, Levitikus. Zweiter Teilband: 16-27 (Freiburg/Breisgau: Herder, 2014), 984; 986f; 1007f, as well as Benjamin Kilchör, Mosetora und Jahwetora. Das Verhältnis von Deuteronomium 12-26 zu Exodus, Levitikus und Numeri (Wiesbaden: Harrassowitz, 2015), 129.

25 Cf. Hieke, Levitikus 16-27, 984; 986.

26 Cf. Georg Braulik, "Erbe" in Wörterbuch alttestamentlicher Motive: 109f.

27 Cf. Braulik, "Erbe", 111. 
early stages onwards, Israel had understood that the land was a gift from God (cf. Dtn 26:5-10). ${ }^{28}$ It is this 'small historical creed' (G. von Rad) of Israel in Dtn 26 which states that Israel had 'become a nation great, strong and numerous' in Egypt - that is, at a time when they were fully detached from their land (Dtn 26:5). The gift of the land as a blessed place flowing with milk and honey (Dtn 26:9, cf. Ex 3:8) was an answer to their cry of affliction (Dtn 26:7). The land thus is a source of consolation in its direct association with God - this describes a theological and not a political reality.

The keyword 'land' is furthermore closely associated with that of the 'temple', ${ }^{29}$ both representing aspects of creation theology: Just as the temple is the earthly representation of the heavenly abode of God, it is also a representation, in nuce, of the whole created cosmos. ${ }^{30}$ Herbert Niehr speaks of the temple as a piece of heaven on earth, that is, the place where the crossover between heaven and earth takes place. ${ }^{31}$ Earlier visions and literary motifs involving God's throne do not envision it as being in heaven, which represents a later development, but places his abode on a holy mountain such as Sinai/Horeb or Zion, which may function as representatives of a cosmic mountain, and are both directly associated with the throne of God. ${ }^{32}$ This creational aspect of land theology is exactly that: theology, far removed from pragmatic politics. In postexilic times, Israel returns to its land, but does not establish a state with a king as its head. Its first concern is the rebuilding of the temple and the reestablishment of its cult (cf. Ezra 1:1-11). ${ }^{33}$

Let us now turn to the third aspect of our considerations, that of 'jurisdiction', as it is represented in the literary figure of the king of Israel.

\section{D 'JURISDICTION' IN BIBLICAL TRADITION}

It is a well-known fact that the Hebrew Bible demonstrates ambiguous approaches to the idea of kingship. Chronologically, the phenomenon begins with King Saul, the election and anointing of whom is narrated in the pre-exilic texts of I Sam 9 and 10. A very sharp, probably exilic, criticism of the idea frames these texts in I Sam 8 and 12. This criticism stands in connection with and corresponds to the admonitions of Dt $17: 14-20,{ }^{34}$ which will form a central part

28 Cf. Ludger Schwienhorst-Schönberger, "Land" in Wörterbuch alttestamentlicher Motive: 299.

29 Cf. Schwienhorst-Schönberger, "Land": 302.

30 Cf. Herbert Niehr, "Tempel” in Wörterbuch alttestamentlicher Motive: 387.

31 Cf. Niehr, "Tempel”, 387.

32 Cf. Frank-Lothar Hossfeld \& Erich Zenger, Psalmen 101-150 (Freiburg/Breisgau: Herder, 2008), 76-78.

33 Personal remark of L. Schwienhorst-Schönberger, 6 June 2019.

34 Cf. Georg Braulik, "Das Buch Deuteronomium" in Einleitung in das Alte Testament (Ed. Erich Zenger and Christian Frevel; Stuttgart: Kohlhammer, 2016), 167; 
of our considerations on jurisdiction. The early view on kingship, as far as narrative texts are concerned, describes the ruler (נגיד) ${ }^{35}$, notably not called 'king' (מלך), הושיע) hip 'il Perf of ישעיר) his people: 'At this time tomorrow I will send you a man from the land of Benjamin whom you are to anoint as ruler of my people Israel. He shall save my people from the hand of the Philistines. I have looked upon my people (ראיתי את־עמי); their cry has come to me (באה צעקתו אלי)' (I Sam 9:16). ${ }^{37}$ The association with Ex 3:7 can hardly be missed: "I have witnessed the affliction of my people (ראה ראיתי את־עני עמירי) ... and have heard their cry ... (ואת־צעקתם שמעתי)".

In the case of the מלך, the positive image presented in the royal Psalms (cf. 2, 20/21, 45, 72, 89, 110), which will not be our main focus of attention, distinguishes itself from the heated exchange of pro- and anti-royalist arguments taking place in the Deuteronomistic History and particularly in the Law of the King, Dt 17:14-20. It is possible, theoretically, to equate the concept of the מלך, the king, with the idea of state. Christian Frevel, in his scholarly and well-

cf. furthermore Eckart Otto, Deuteronomium 12,1-23,15 (Freiburg/Breisgau: Herder, 2016), 1481, who includes the contents of I Sam 10 into his considerations concerning the Law of the King.

35 Hasel, נגיד: 207f, considers different etymologies for the term and concludes that the most likely choice should be that of the נגיד being 'high-born'. A roughly contemporary Old Aramaic text (the stele Sefire III, cf. TUAT I, 178) contains the term in a context which would require a similar rendering: King Bar-Ga'yah of Ktk draws up a treaty with King Mati'-Il of Arpad, in which he lists a number of possible adversaries who are not to be aided by Mati'-Il, should they seek refuge in Arpad, plot against king Bar-Ga'yah, or even only speak evil against him. Apart from the king's guards, brothers, members of his dynasty, eunuchs, or members of his people, BarGa'yah also mentions a group designated with $n g d$ and translated with "meine Hohen" - my high-born. A $n g d$ can therefore be considered as a nobleman or member of the aristocracy, to describe the concept somewhat anachronistically (cf. TUAT I, 186f; Hasel, נגיד: 203).

36 Hasel, נגיד: 209, remarks for the early monarchic period (“in frühstaatlicher Zeit"): "Im Königstitel hat das politische Element Hauptbetonung, während im $n \bar{a} \bar{g} \hat{\imath} \underline{d}$-Titel das religiös-sakrale Element im Vordergrund steht". As will become clear in our investigation of the Law of the King, we can already see here that the title מלך had evolved to gain an increasingly theological meaning - although initially being far from devoid of political meaning.

37 Hasel, נגיד: 212f, confirms the above-mentioned meaning of נגיד as a 'high-born' designated king particularly for I Sam 9:16 and emphasizes the saving (ישעי) role of Saul as נגיד in this context. The fact that he is anointed as such by the man of God, Samuel (I Sam 10:1), is to be distinguished from his being proclaimed king by the people (I Sam 10:24) and from his later anointing as king by Samuel (I Sam 15:1). The latter two acts display a markedly stronger political character, as can be seen, for instance, when God announces punishment for Amalek directly after the second anointing and this is carried out by Saul in a military operation (cf. I Sam 15:2-9). 
researched Geschichte Israels, however, uses 'state' for a period as early as the $10^{\text {th }}$ to $9^{\text {th }}$ centuries $\mathrm{BCE}$, thus, from a reader's perspective, clearly premonarchically, ${ }^{38}$ as does Walter Oswald, who holds the concept of a Mosaic state for the desert generation. ${ }^{39}$ In this, Oswald applies a curious mixture of an historical and a literary approach to his subject matter, which one might question for its methodology. Frevel's purely historical approach would allow for his usage of 'state', more than is the case for authors working on an inner-biblical textual basis. ${ }^{40}$ Frevel's criterion is the extra-biblical, that is, archaeological, iconographical and epigraphical evidence of a political entity called 'Israel'. Our concern here is much rather the biblical portrayal of social functions in interaction with theological considerations. ${ }^{41}$ We have seen thus far that a diachronic reading of the relevant texts often reveals politically oriented earlier textual layers that gain increasing theological relevance as Israel's thought on these themes develops. On the biblical end text level, neither the element of 'land' nor that of 'people' solely carries political weight, 'land' even to a lesser extent than 'people'; rather, they are terms with theological significance. I would agree with Friedhelm Hartenstein and Jutta Krispenz when they postulate that

38 Cf. Christian Frevel, Geschichte Israels (Stuttgart: Kohlhammer, 2016), 31.

39 Cf. Oswald, "Königtum und Staat", 198.

40 Perlitt, "Staatsgedanke", uses the text and not archaeological evidence as the foundation for his reflections. Unfortunately, this contribution of Perlitt, although containing many valuable observations, nevertheless also displays his typical trait of sharply polemicizing against colleagues or concepts that do not suit his frame of thought - an aspect which diminishes the factual value of that which he was trying to communicate. Perlitt's particular target in this case was Norbert Lohfink's influential 1971 contribution, in our contribution referred to under the short title "Sicherung der Wirksamkeit", in which Lohfink introduced the novel idea of the Laws of the Offices being a kind of precursor to the political idea of the separation of powers. This idea was later taken up enthusiastically by Christa Schäfer-Lichtenberger ("Der deuteronomische Verfassungsentwurf. Theologische Vorgaben als Gestaltungsprinzipien sozialer Realität" in Bundesdokument und Gesetz: Studien zum Deuteronomium [ed. Georg Braulik; Freiburg/Breisgau: Herder, 1995]) as well as by Bernard Levinson ("The First Constitution. Rethinking the Origins of Rule of Law and Separation of Powers in Light of Deuteronomy" [Cardozo Law Review 27:4, 2006]). Retrospectively Lothar Perlitt's verbal attack could have been spared or at least mitigated, had he been willing to recognise that Norbert Lohfink's "Sicherung der Wirksamkeit" does not argue for a strictly political interpretation of the Law of the King, but rather ultimately emphasises the great importance attached to the Torah and the Law of the Prophet as a corrective to the king's actions, which places its subject matter firmly in a theological context.

41 Udo Rüterswörden's 1987 study of the Laws of the Offices, Von der politischen Gemeinschaft zur Gemeinde: Studien zu Dt 16,18-18,22 (Frankfurt/Main: Athenäum), for instance already reveals the direction of thought in its title (translated: From political community to congregation). He solves the political-theological dichotomy along historical lines, arguing for a pre-exilic political community that translates into an exilic community with theological interests in the Law of the King. 
the Old Testament ultimately does not present us with a model of a secular state or a worldly king. ${ }^{42}$

Keeping in mind the plethora of royal references throughout the Old Testament and the diverse images of kingship associated with these, it is the Deuteronomic Law of the King that will guide our closing considerations on biblical 'state' thought. Eckart Otto points out that the historicizing introduction to the Law of the King (Dtn 17:14a) binds the constitution of the offices, in their especial Deuteronomic form and according to their narrated time, to the land. ${ }^{43}$ Lothar Perlitt sees the exact opposite in the introduction of v. 14 and emphasizes that it has a 'de-historicizing' (enthistorisierende) function. His conclusion is of especial interest for our theme: according to Perlitt, the law is embedded into the 'Moses-fiction' and does not wish to provide information on any geographical or historical reality in which the ideal kingdom is to be realised. ${ }^{44}$ Whether seen as 'historicizing' or 'de-historicizing': the descriptions offered by the two authors both can lead to the conclusion that, to use our terminology, territory and jurisdiction join forces in Dtn 17:14 to result, ultimately, in a theological rather than a political statement. For Otto, the Law of the King is an expression of the universality of the jurisdiction of YHWH as opposed to that of an outlandish royal figure. ${ }^{45}$

Although the relative dating of the laws of the Deuteronomic law code is the subject of heated debate, a number of scholars do reach the consensus that the Deuteronomic Laws of the Offices, and for our purposes, especially the Law of the King, can be dated to the exilic period in its earliest form. Often, they also reckon with a later revision of the same, which even might be dated later, at the level of the Deuteronomic end redaction. ${ }^{46}$ The use of the term 'torah' in Dtn

42 Cf. Friedhelm Hartenstein \& Jutta Krispenz, "König, Gott als König,” Wörterbuch alttestamentlicher Motive: 272.

43 Cf. Eckart Otto, Deuteronomium 12,1-23,15 (Freiburg/Breisgau: Herder, 2016), 1480 .

44 Cf. Perlitt, "Staatsgedanke", 192.

45 Cf. Otto, Deuteronomium 12,1-23,15, 1483.

46 Cf. Norbert Lohfink, "Die Sicherung der Wirksamkeit des Gotteswortes durch das Prinzip der Schriftlichkeit der Tora und durch das Prinzip der Gewaltenteilung nach den Ämtergesetzen des Buches Deuteronomium (Dt 16,18-18, 22)" in Testimonium Veritati: FS Wilhelm Kempf (ed. H. Wolter, Frankfurt: Knecht, 1971), 149; likewise Eckart Otto, Theologische Ethik des Alten Testaments (Stuttgart: Kohlhammer, 1994) 196f; - Otto, however, also presents arguments for a post-exilic revision of the Law of the King, cf. Eckart Otto, Deuteronomium 23,16-34,12 (Freiburg/Breisgau: Herder, 2017), 2010. In both cases, he emphasizes the utopian character of this law, seeing that it has its exilic roots in a 'landless' situation and its post-exilic roots in a 'kingless' situation. He also takes pains to explain that the term 'utopia' does not describe a sense of loss of reality, but rather refers to an ideal that serves to highlight contemporary grievances by conjuring up an ideal future. For exilic times, thus Otto (cf. Ethik, 196), 
17:18 might be taken as an indication of a late redaction, since this term cannot possibly mean the same according to the narrated time of v. 18 as it does, when understood in its broader sense in later poetry and wisdom literature, and even today, comprising the full Pentateuch with its halachic and haggadic contents. Alternatively, one might consider the 'torah' of Dtn 17:18 as a kind of selfreference, that is, pointing to an early collection of laws that roughly corresponds to the contents of the Deuteronomic law code itself. ${ }^{47}$

According to Dtn 17:15, the king is to be chosen by God and installed by Israel from among their brothers - meaning that he has to be a fellow Israelite. ${ }^{48}$

In the book of Deuteronomy, throughout the corpus of its social law, the word 'brother' is used as a synonym for the poor and the needy within the people of Israel ${ }^{49}$ If the Deuteronomic Laws of the Offices, ${ }^{50}$ and specifically the Law of the King, use the very same term, אח, for the 'pool' of candidates from which the king, priests, or prophet(s) are to come, it has - what secondary literature calls - democratising implications for the role of the king as envisioned by Deuteronomy. The social laws of Deuteronomy and Leviticus mainly use אח the singular, because it is the individual impoverished brother whom assistance

the Law of the King has a decidedly critical function, creating a foil against which the prevailing conditions of the neo-Assyrian and neo-Babylonian period are to be seen. Georg Braulik, "Das Buch Deuteronomium", 167, places these laws into the broader context of the exilic and early post-exilic situation and describes it as a 'realistic utopia', whereas Lothar Perlitt ("Staatsgedanke", 185) questioned the notion of a utopia for this textual situation. Hans Ulrich Steymans argues for a layered development of the Laws of the Offices, with the Law of the King initially bearing a strong juridical character, grounded in and not removed from the reality of its Ancient Near Eastern surroundings, (personal communication, 21/04/2020).

47 Cf. Georg Braulik, "Die Ausdrücke für 'Gesetz' im Buch Deuteronomium" in Biblica 51 (1970): 66.

48 For an extensive exegesis of the Law of the King and a discussion of the theological implications of the king as 'brother', cf. Johanna J. Friedl, "Ein brüderliches Volk. Das 'Bruder'-Konzept im Heiligkeitsgesetz und deuteronomischem Gesetz" (Dr. theol. thesis, University of Vienna, 2017), 139-153; 257-264. Online: http://othes.univie.ac.at/50804/. Eckart Otto (Deuteronomium 12,1-23,15, 1482f) associates this requirement with criticism against prophetic voices from Deutero-Isaiah and Jeremiah, which ascribe royal dignity, valid also for Israel, to foreign figures such as Nebuchadnezzar and Cyrus II. If this were to be the case, then the Law of the King, at this later redactional stage, withdraws the theme of kingship from the (international) political realm to place it in a theocratic-theological context. The remarks about its being a utopic ideal (cf. FN 46) confirm the theological quality of this law. It reaches its theological zenith in v. 18-20, in which the brother-king is admonished to write down a copy of the Torah and study it diligently.

49 This can be seen particularly in Dt 15:1-18; $23: 20 f ; 24: 10-15$ as well as in Lev 25:23-55, cf. Friedl, "Ein brüderliches Volk", 71-113; 201-221; 227-232.

50 Dt 17:14-20; 18:1-8, 15-22. 
is to be given to. The Laws of the Offices, on the other hand, use the word in the plural, indicating communality. ${ }^{51}$ The office-bearer, be it the king or a prophet, arises from the midst of the larger group of brothers.

The Law of the King sharply reduces or even completely does away with the legislative, judicative, and executive functions normally associated with oriental kingship. ${ }^{52}$ In the famous formula used by Norbert Lohfink, ${ }^{53}$ this law describes him as the 'model Israelite' whose prime responsibility is the daily study of the Torah. His function as prime student in Israel has got very little to do with that which we today understand when we use the word 'jurisdiction'. As Eckart Otto aptly puts it, if Moses' addressees wish to have a king as all the surrounding nations do, then the Law of the King proclaims that they will be given the exact opposite - a king who differs from all other kings in every important aspect. ${ }^{54}$

A recent detailed publication by Dominik Markl $^{55}$ provides some guidelines for our concluding thoughts on the meaning of this law. He speaks about "a double nature, which appears self-contradictory or at least in tension with itself" when referring to the book of Deuteronomy. ${ }^{56}$ The basic tension lies between the description of the socio-political reality of the day and the theological message of the text, or, as Markl puts it, between a historicized aetiology and a political programme. Note that in the first pair of alternatives, which represents my personal suggestion for the solution of our dichotomy, history and politics belong together, and programmatic theology is their counterpart. In Markl's Deuteronomy, history and (theological) aetiology team up against (or with?) a political programme. In a giveaway sentence, he tells us early on: "Historicized etiology, utopian conception, and political ideology may well flow into each other in this peculiar text". ${ }^{57}$ Markl convincingly places the law of the king against the background of a failed monarchy, ${ }^{58}$ which means that it is roughly to be given neither a particularly early (i.e., pre-exilic) date, nor a particularly late post-exilic date. This would agree with an exilic or early postexilic dating as discussed earlier, this being a period in which the question of why so much went wrong in the implementation of the concept of monarchy in

51 Cf. Friedl, "Ein brüderliches Volk", 34.

52 Cf. Bernard Levinson, "The Reconceptualisation of Kingship in Deuteronomy and the Deuteronomistic History's Transformation of Torah" VT 51/4 (2001) 511-534, 527ff; likewise Otto, Deuteronomium 12,1-23,15, $1484 \mathrm{f}$.

53 Cf. Lohfink, "Sicherung der Wirksamkeit", 150.

54 Cf. Otto, Deuteronomium 12,1-23,15, 1484; 1486.

55 Cf. Dominik Markl, “Deuteronomy's 'Anti-King'. Historicized Etiology or Political Program?" in Changing faces of Kingship in Syria-Palestine 1500-500 BCE (ed. Agustinus Gianto and Peter Dubovský; Münster: Ugarit, 2018) 165-186.

56 Cf. Markl, “Anti-King”, 167.

57 Markl, "Anti-King”, 173.

58 Cf. Markl, "Anti-King”, 174. 
Israel/Judah would have been a very live and present one which was debated, as Markl points out, in the absence of a monarch. ${ }^{59}$

The Septuagint makes a fine distinction in its rendering of the Law of the

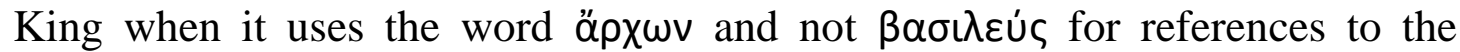
Israelite מלך. Throughout Deuteronomy, the LXX reserves $\beta \alpha \sigma i \lambda \varepsilon u ́ c ̧$ for foreign

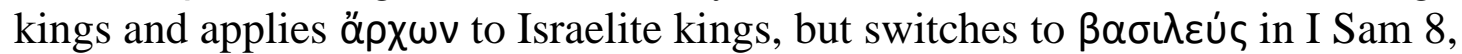
underscoring the critical undertone of that chapter. ${ }^{60}$ ópx $\omega v$ is also the term used to designate the נגיד of I Sam 9:16, which, as we have learned from Gerhard Hasel's observations $^{61}$, is the term that carries theological weight as opposed to the more political מלך of early redactional layers. The LXX translators apparently sensed something which the texts we have consulted also reveal: that even the pre-monarchical, more so the (early) post-exilic, and certainly the latest Deuteronomic and Deuteronomistic conceptions of rulership are devoid of the idea of absolute monarchic jurisdiction of a strictly political type. ${ }^{62}$ In the words of Dominik Markl:

The different priestly groups behind the traditions of the Pentateuch seem to converge in their esteem for humility as a political virtue. As long as there is no real king in postexilic Jerusalem, the portrait of a humble king shows what an ideal leader should be: a diligent student of Mosaic torah. As long as this king's imagined throne is empty, leadership duties may well be fulfilled by those who live his task to perfection - the priestly experts in Mosaic torah. Since Deuteronomy commands not only the king but also the entire people to study torah (6:6-9; 31:9-13), the humble king may well be an exemplary Israelite. ... Eventually, all Israelites may be endowed with royal dignity by studying 'this torah'. 63

\section{E CONCLUSION: THE BIBLE AND CONTEMPORARY STATE THEORY}

Returning now to contemporary conceptions of state, we again must remind ourselves that the concept itself is essentially a modern one. As Josef Isensee points out: formulating a conception of 'state' which includes too many epochs only leads to fuzziness of definition. ${ }^{64}$ The solution to this problem would be to reduce the temporal framework of an attempted definition of 'state', and in our day that would naturally lead to using the modern, Western state as template for

\footnotetext{
59 Cf. Markl, “Anti-King”, 175.

60 Cf. Markl, “Anti-King”, 176.

61 Cf. FN 36 and 37 above.

62 Cf., too, the observation by Robert Hanhart quoted at Markl, "Anti-King”, 176: ä $\rho \chi \omega v$ is "adequate both for the pre-exilic monarchical representative and also for the post-exilic high-priestly one".

63 Mark1, “Anti-King”, 180.

64 Cf. Isensee, "Staat", 742.
} 
such a definition, which is quite legitimate in political theory and philosophy of law. However, applying this complex construct to pre-modern scenarios, and that is especially true for the case of biblical Israel, introduces concepts into biblical material, which are intrinsically foreign to it or which can be found in the Bible as precursors of the grand conceptions we now cherish as achievements of enlightened society. ${ }^{65}$

Josef Isensee argues in favour of the usage of the word 'state' also for premodern scenarios because our languages, be they German or English, provide us with no better option. Since Machiavelli, many different nuances of the exercise of power gradually became incorporated under one heading: the word 'state'. This includes, as was mentioned at the onset, not only broadly the ideas of people, territory, and jurisdiction, but also finer theoretical distinctions best expressed in their Latin original, such as res publica, civitas, regnum, regimen, imperium, and potestas. ${ }^{66}$

The biblical texts we have considered, however, do not at all deal with many of these concepts. In other cases, these concepts or analogies to them might very well be traced back to our biblical texts, but then the biblical texts do not primarily deal with the conceptions of common good ('Gemeinwesen'/res publica), citizenship and civil action ('Bürgerschaft'/civitas), reign ('Herrschaft'/regnum), government ('Führung'/regimen), official authority ('Amtsgewalt'/imperium), and power ('Macht'/potestas) ${ }^{67}$ for their own sake, but at most for the sake of their being an expression of the state or condition of Israel's relationship with God. Even the relationships among fellow men or 'brothers' within Israel are an expression of Israel's being a community living coram deo.

It would be an unfair claim towards knowing the mind of each exegete applying the word 'state', should one assert that exegetes generally use this word anachronistically. I do, however, wish to make us aware of the pitfalls of its usage and of the rich history of ideas accompanying it today. I would further

65 Here one might point to the contributions of Georg Braulik, whose 1986 article titled "Das Deuteronomium und die Menschenrechte" (ThQ 166: 8-24) traces the roots of the 1948 universal declaration on Human Rights back to the ideas of the book of Deuteronomy. A more recent contribution in the same vein would be the monograph of Gerhard Lohfink, titled: Im Ringen um die Vernunft. Reden über Israel, die Kirche und die Europäische Aufklärung (Freiburg/Br.: Herder, 2016), in which he treats different enlightenment ideas and contemporary questions of society in the light of their early biblical counterparts or precursors. Finally, the encyclopaedic monograph of Arnold Angenendt, Toleranz und Gewalt: Das Christentum zwischen Bibel und Schwert (Münster: Aschendorf, 2009) devotes itself to tracing enlightenment principles to their Christian, and implicitly, biblical roots.

66 Cf. Isensee, "Staat", $742 \mathrm{f}$.

67 Cf. Isensee, "Staat", 742f. 
wish to place a caveat on sweeping statements about the Bible being a political book - something, again, not seldom heard at least in medial discussions of the relation between Bible and politics today. Yes, the Bible does contain many texts which touch on our political realities. But if we reduce its statements to words with relevance only for, say, calls toward civil courage, or for the criticism of human decisions made by politicians, we reduce the enormous theological gravity of biblical dealing with these topics. The biblical people of God is described as a people of God, its land essentially belongs to God, and its king primarily should be a student of the Torah of God. For Israel's ideal king as he is described in Deuteronomy, the end text leaves us with little of a political handle to hold onto. Yes, 'the people' wish him to be installed, once they enter into 'the land', but we have seen that the setting of his kingship most probably serves to conjure up a utopia, criticising the political situation of the different phases in which this law was introduced into and reworked in the context of the book of Deuteronomy. The king's study of the Torah should remind him that he is a brother among brothers and that his heart should not be exalted above his brothers.

Let us therefore recall Dominik Markl's closing quotation about the Law of the King and allow ourselves essentially to be reminded of one matter: of the greatness of humility as a political virtue.

\section{BIBLIOGRAPHY}

Angenendt, Arnold. Toleranz und Gewalt: Das Christentum zwischen Bibel und Schwert. Münster: Aschendorf, 2009.

Bergsma, John S. The Jubilee from Leviticus to Qumran. A History of Interpretation.

VT.S 115. Leiden: Brill, 2007. https://doi.org/10.1163/ej.9789004152991.i-353.

Braulik, Georg. "Die Ausdrücke für 'Gesetz' im Buch Deuteronomium.” Biblica 51 (1970): 39-66.

. "Das Deuteronomium und die Menschenrechte." ThQ 166 (1986): 8-24.

"Das Buch Deuteronomium." Pages 152-182 in Einleitung in das Alte Testament. Edited by Erich Zenger and Christian Frevel. 9th ed., Stuttgart: Kohlhammer, 2016.

. "Erbe." Pages 109-112 in Wörterbuch alttestamentlicher Motive. Edited by M. Fieger, J. Krispenz \& J. Lanckau. Darmstadt: WBG, 2013.

Filmer, Sir Robert. Patriarcha and other Writings. Edited by Johann P. Sommerville. Cambridge Texts in the History of Political Thought. Cambridge: Cambridge University Press, 1991. https://doi.org/10.1017/CBO9780511812644.

Frevel, Christian. Geschichte Israels (Stuttgart: Kohlhammer, 2016).

Friedl, Johanna J. 'Ein brüderliches Volk. Das 'Bruder'-Konzept im Heiligkeitsgesetz und deuteronomischem Gesetz." Dr. Theol. thesis, University of Vienna, 2017. Online: http://othes.univie.ac.at/50804/. https://doi.org/10.25365/thesis.50804.

Groß, Walter. Richter. HThK.AT. Freiburg/Breisgau: Herder, 2009.

Halbe, Jörn. Das Privilegrecht Jahwes Ex 34,10-26. Gestalt und Wesen, Herkunft und Wirken in vordeuteronomischer Zeit. Göttingen: Vandenhoeck \& Ruprecht, 1975. https://doi.org/10.13109/9783666532696. 
Hartenstein, Friedhelm \& Jutta Krispenz. “König, Gott als König.” Pages 272-279 in Wörterbuch alttestamentlicher Motive. Edited by M. Fieger, J. Krispenz \& J. Lanckau. Darmstadt: WBG, 2013.

Hasel, Gerhard."נגידד". Pages 203-219 in vol. 5 of Theologisches Wörterbuch zum Alten Testament. Edited by G. Johannes Botterweck, Helmer Ringgren, and HeinzJosef Fabry. 8 vols. Stuttgart: Kohlhammer, 1986.

Hieke, Thomas. Levitikus. Zweiter Teilband: 16-27. HThK.AT. Freiburg/Breisgau: Herder, 2014.

Hobbes, Thomas. Leviathan. Edited with an Introduction and Notes by J.C.A. Gaskin. Oxford World's Classics. Oxford: Oxford University Press, 1996.

Hossfeld, Frank-Lothar \& Erich Zenger. Psalmen 101-150. HThK.AT. Freiburg/ Breisgau: Herder, 2008.

Isensee, Josef. "Staat." Pages 741-774 in Handbuch der Katholischen Soziallehre. Edited by Anton Rauscher. Berlin: Duncker \& Humblot, 2008.

Kaiser, Otto et al., eds., Texte aus der Umwelt des Alten Testaments. Bd. I: Rechts- und Wirtschaftsurkunden. Historisch-chronologische Texte. Gütersloh: Gütersloher Verlagshaus, 1982-85; Lizenzausgabe Darmstadt: Wissenschaftliche Buchgesellschaft, 2019.

Kilchör, Benjamin. Mosetora und Jahwetora. Das Verhältnis von Deuteronomium 1226 zu Exodus, Levitikus und Numeri. BZAR 21. Wiesbaden: Harrassowitz, 2015. https://doi.org/10.2307/j.ctvc2rmx0.

Levinson, Bernard M. "The Reconceptualization of Kingship in Deuteronomy and the Deuteronomistic History's Transformation of Torah." VT 51/4 (2001): 511-534. "The First Constitution. Rethinking the Origins of Rule of Law and Separation of Powers in Light of Deuteronomy." Cardozo Law Review 27:4 (2006): 18531888.

Locke, John. Two Treatises of Government. Edited with an Introduction and Notes by Peter Laslett. Cambridge Texts in the History of Political Thought. Cambridge: Cambridge University Press, 1988.

Lohfink, Gerhard. Im Ringen um die Vernunft: Reden über Israel, die Kirche und die Europäische Aufklärung. Freiburg/Breisgau: Herder, 2016.

Lohfink, Norbert. "Beobachtungen zur Geschichte des Ausdrucks עם יהוה". Pages 275305 in (ed.), Probleme biblischer Theologie. Gerhard von Rad zum 70. Geburtstag. Edited by H.W. Wolff. München: Kaiser, 1971; repr. pages 99-132 in Studien zur biblischen Theologie. Stuttgarter biblische Aufsatzbände AT 16. Stuttgart: Katholisches Bibelwerk, 1993.

. "Die Sicherung der Wirksamkeit des Gotteswortes durch das Prinzip der Schriftlichkeit der Tora und durch das Prinzip der Gewaltenteilung nach den Ämtergesetzen des Buches Deuteronomium (Dt 16,18-18,22)." Pages 143-155 in Testimonium Veritati. FS Wilhelm Kempf. Edited by H. Wolter. FTS 7. Frankfurt: Knecht, 1971; repr. pages 305-323 in Studien zum Deuteronomium und zur deuteronomistischen Literatur I. Stuttgarter biblische Aufsatzbände AT 8. Stuttgart: Katholisches Bibelwerk, 1990.

Markl, Dominik. "Deuteronomy's 'Anti-King'. Historicized Etiology or Political Program?" Pages 165-186 in Changing faces of Kingship in Syria-Palestine 1500500 BCE. Edited by Agustinus Gianto and Peter Dubovský. AOAT 459. Münster: Ugarit, 2018. 
Perlitt, Lothar. "Der Staatsgedanke im Deuteronomium.” Pages 182-198 in Language, Theology and the Bible. Essays in Honour of James Barr. Edited by S. Balentine and J. Barton. Oxford: Clarendon Press, 1994.

Niehr, Herbert. "Tempel." Pages 387-391 in Wörterbuch alttestamentlicher Motive. Edited by M. Fieger, J. Krispenz \& J. Lanckau. Darmstadt: WBG, 2013.

Nihan, Christophe. From Priestly Torah to Pentateuch. FAT II/25. Tübingen: Mohr Siebeck, 2007. https://doi.org/10.1628/978-3-16-151123-3.

Oswald, Wolfgang. "Königtum und Staat." Pages 197-210 in Die Welt der Hebräischen Bibel. Umfeld - Inhalte - Grundthemen. Edited by Walter Dietrich. Stuttgart: Kohlhammer, 2017.

Otto, Eckart. Theologische Ethik des Alten Testaments. Stuttgart: Kohlhammer, 1994. Deuteronomium 12,1-23,15. HThK.AT. Freiburg/Breisgau: Herder, 2016. Deuteronomium 23,16-34,12. HThK.AT. Freiburg/Breisgau: Herder, 2017.

Rüterswörden, Udo. Von der politischen Gemeinschaft zur Gemeinde: Studien zu Dt 16,18-18,22. BBB 65. Frankfurt/Main: Athenäum, 1987.

Schäfer-Lichtenberger, Christa. "Der deuteronomische Verfassungsentwurf. Theologische Vorgaben als Gestaltungsprinzipien sozialer Realität." Pages 105118 in Bundesdokument und Gesetz: Studien zum Deuteronomium. Edited by Georg Braulik. HBS 4. Freiburg/Breisgau: Herder, 1995.

Schwienhorst-Schönberger, Ludger. "Land." Pages 299-305 in Wörterbuch alttestamentlicher Motive. Edited by M. Fieger, J. Krispenz \& J. Lanckau. Darmstadt: WBG, 2013.

Von Schlieffen, Katharina \& Jenny Nolting. Rechtsphilosophie. Grundlagen für das Jurastudium. UTB 4856. Paderborn: Verlag Ferdinand Schöningh, 2018.

Wilson, Peter H. The Holy Roman Empire. A Thousand Years of Europe's History. London: Penguin Random House, 2017. https://doi.org/10.4159/9780674915909.

Johanna Friedl is research associate at the Department of Old Testament and Hebrew Scriptures, Faculty of Theology and Religion, University of Pretoria and copy editor at the Institute for Urban and Regional Research, Austrian Academy of Sciences. She teaches Old Testament and Hebrew Language at the Theological Courses of the Roman Catholic Archdiocese of Vienna. E-mail: johanna.friedl@ oeaw.ac.at ORCID: https://orcid.org/0000-0002-3935-7993. 